\title{
Dampak Usaha Tabulampot Rumah Tangga Terhadap Pendapatan Keluarga
}

\author{
ASNAHWATI \\ Sekolah Tinggi Ilmu Ekonomi Riau \\ Jln. HR Subrantas KM 12 Panam Pekanbaru \\ E-mail : asnahwati357@yahoo.com
}

\begin{abstract}
Tabulampot business can be used as a side business for women especially housewives who live in modest housing. Limited and even narrow land that is in the yard of the house can be optimized function by planting various types of plants in pots. This system is known as Tabulampot. The results of this plant is expected to increase family income. In addition to the results can be sold, can also be consumed by yourself so as to save household expenses. In real terms, these savings are seen as increasing family income. The long-term goal of this research is to increase Tabulampot's results so that it can also increase family income. But what happened so far from the observations that the author has done around the modest housing, Tabulampot business is really only used as a side activity that is not so expected results. Proven from the Tabulampot display and the results obtained are not optimal. Yet if this business is really managed properly it will be able to bring optimal results that will be able to increase family income. This research is focused on respondents who have Tabulampot in simple housing complex. In this study, a sample of 18 people from all housewives who have Tabulampot in RT 0I RW 02 Housing Wisma Kualu Permai Tarai Bangun Kecamatan Tambang Kabupaten Kampar Riau. After doing the research, it is known that Tabulampot's business done by housewife is only for the mere pleasure which is not so expected result. The mothers lack good financial management of this business especially the evaluation of business results so it is known that the impact of this effort on the increase in family income is still small that is $16.7 \%$.. From the study also known the most important obstacle experienced by housewife housewives This simplification is in terms of care and management.
\end{abstract}

Keywords: Management, Family income

Budi daya buah dalam pot atau yang biasa disebut Tabulampot semakin banyak digemari karena cara ini dianggap sangat efektif bagi para pecinta tanaman buah yang ingin menanam buah-buahan dengan memanfaatkn lahan yang sempit. Selain bisa menghasilkan buah, Tabulampot buah mampu menghasilkan buah yang lezat juga sebagai penghias rumah. yang paling indah jika melihat tanaman buah yang kita tanam tersebut. Melihat buahnya yang bergelantungan membuat tertarik orang yang melihat sehingga ingin memetik dan memakannya. Selain buah, tanaman lain juga bisa dijadikan tabulampot. Seperti tanaman hias, tanaman obat-obatan atau biasa disebut juga apotik hidup dan bumbu dapur.
Di zaman modern ini, peran perempuan dalam meningkatkan pendapatan keluarga perlu diperhitungkan. Tabulampot adalah salah satu usaha sampingan yang dapat dilakukan untuk menambah pendapatan keluarga. Dengan menggunakan lokasi yang terbatas dari pekarangan rumah sederhana yang mereka tempati, mereka menanam bibit buah dalam sebuah pot, diantaranya jeruk kesturi, jeruk manis, jeruk sankis, jambu madu, jambu biji bangkok, jambu biji kristal dan lain-lain. Dengan menghasikan buah untuk dikonsumsi sendiri akan bisa menghemat pengeluaran rumah tangga atau bisa juga dikatakan meningkatkan pendapatan keluarga secara riil. 
Menurut Wibowo

(2015) Tabulampot adalah teknik budidaya tanaman yang menggunakan pot dan sejenisnya sebagai tempat meletakkan media tanam dan bibit tanaman. Teknik tabulampot dapat menggunakan tempat berupa pot plastik, pot dari tanah liat dan berbagai bahan yang dapat dicetak, dan polybag atau plastik (Wibowo, Ananda, Setiawan, Prahendra, \& Adelin, 2015).

$$
\text { Teknik tabulampot memiliki }
$$

kelebihan dan kekurangan. Kelebihan teknik ini yaitu: praktis, tidak memerlukan banyak media dan pupuk (sesuai ukuran pot yang mampu menampung media) dan harga relatif murah. Kelemahannya yaitu terbatas jumlah dan jenis tanaman yang dapat ditampung di tabulampot. Tabulampot dapat dijadikan sebagai solusi praktis dalam menyikapi kondisi dan permasalahan masyarakat akan keterbatasan lahan pertanian. Tabulampot juga dapat menumbuhkan kembali rasa cinta kita terhadap produk pertanian.Tidak jarang masyarakat menggantungkan hidupnya pada budidaya tanaman dengan teknik tabulampot, karena hasilnya yang lebih tinggi dibanding teknik lainnya(Wibowo et al., 2015)

Namun yang terjadi selama ini penulis perhatikan serta dari observasi yang telah dilakukan diketahui bahwa usaha Tabulampot hanya dijadikan usaha sampingan yang tidak begitu diharapkan hasilnya. Hal ini bisa dilihat dari tampilan dan kesuburan tanaman dimana banyak ditemui tanaman yang kurang sehar dan dijumpai banyak rumput yang tumbuh dibiarkan begitu saja di dalam pot tersebut. Hal ini menandakan kurangnya perawatan dan perhatian terhadap tabulampot yang telah ditanam.

Dalam pengelolaan Tabulampot ini membutuhkan juga jiwa kewirausahaan. Sebagaimana dinyatakan Sari, adanya jiwa enterpreneur sangat diperlukan bagi pengembangan individu dalam mengarungi kehidupan disamping secara lebih luas lagi yaitu untuk mengembangkan kemandirian bangsa. Wirausaha bukan sekedar berbisnis apalagi sekedar berdagang, hal ini penting untuk dimengerti agar tidak terjadi kesalahan arti dan pemahaman yang sempit. Maka dari itu, kegiatan Tabulampot yang dilakukan oleh ibu rumah tangga bisa juga dikatakan sebagai wirausaha. Budaya Kewirausahaan yang tumbuh secara alami dalam suatu keluarga atau kelompok masyarakat Indonesia merupakan suatu aset yang sangat berharga bagi bangsa Indonesia.(Sari, 2014)

Usaha ibu-ibu perumahan sederhana dalam menanam Tabulampot ini termasuk juga ke dalam usaha Mikro Kecil Menengah (UMKM) yang membutuhkan jiwa kewirausahaan, sebagaimana Rambat Lupiyoadi Jero Wacik mendifinisikan bahwa enterpreneur (wirausaha) adalah kegiatan yang melaksanakan proses penciptaan kekayaan dan nilai tambah melalui peneloran dan penetasan gagasan, memadukan sumber daya dan merealisasikan gagasan tersebut menjadi kenyataan. Enterpreneur (wirausaha) adalah suatu proses peningkatan kesejahteraan yang dinamis.(Sari, 2014)

Hasil penelitian dari Wicaksono menyimpulkan bahwa wirausaha wanita dalam mengelola usahanya telah mendasarkan pada dimensi inovasi, dimensi pengambilan resiko dan sikap proaktif dalam pengembangan usaha. Meskipun implementasi inovasi belum maksimal akan tetapi pelaku usaha secara terus menerus berupaya untuk meningkatkan inovasi baik dari sisi pengembangan produk, cara kerja maupun sistem pemasaran. Sejumlah upaya yang dilakukan antara lain dengan terlibat secara aktif pada kegiatan pembinaan dan pendampingan UMKM yang dilakukan oleh instansi pemerintah maupun swasta. Akan tetapi dalam upaya pengembangan inovasi produk, sistem kerja maupun sistem pemasaran, para pelaku usaha masih terkendala dengan kemampuan sumber daya manusia yang ada mengingat SDM yang terlibat dalam pengelolaan 
UMKM rata-rata kurang memiliki pemahaman yang baik di bidang bisnis atau tata kelola usaha.(Wicaksono, 2015)

Menurut Drs. H. Hendro Sunarjo, APU (Purn) dalam bukunya hal 8 mengemukakan pendapat bahwa tabulampot bisa menjadi solusi bagi masyarakat perkotaan yang hanya memiliki lahan terbatas dan ingin menanam tanaman buah disekitar rumahnya. Tak hanya sebagai tanaman hias saja, kenikmatan lain dari tabulampot adalah kita bisa juga menikmati buahnya. Dari sisi estetika, tabulapot tidak kalah dengan tanaman hias lainnya. Sebagai gambaran, tabulampot yang rimbun dapat memperindah halaman rumah, terutama jika ditata dan dirawat dengan baik.(Wiguna \& Ekadewi, 2016)

Bagi perempuan yang betul-betul melakukan pengelolaan Tabulampot dengan baik dan optimal maka mereka akan mendapatkan tujuan yang mereka harapkan dengan baik, diantaranya manfaat ekonomi dan manfaat lingkungan sosial. Manfaat ekonomi diantaranya adalah: menghemat pengeluaran rumah tangga untuk membeli buah dan menghemat pengeluaran untuk berekreasi. Menghemat pengeluaran rumah tangga untuk membeli buah bisa juga dikatakan bahwa secara tidak langsung bisa meningkatkan pendapatan secara riil dimana dengan menghasilkan sendiri buah yang dibutuhkan akan mengurangi pengeluaran rumah tangga untuk membeli buah sebagaimana biasanya. Begitu juga dalam hal rekreasi. Dengan merawat tanaman dengan penuh kasih sayang sehingga tampilannya menarik hati sebagaimana halnya tanaman hias lainnya, maka hal ini sudah bisa dijadikan sebagai pengganti rekreasi. Namun bagi mereka yang tidak ikut mengelola Tabulampot maka mereka tidak akan mendapatkan manfaatnya.

Wirausaha yang sukses pada umumnya adalah mereka yang memiliki kompetensi yaitu: seseorang yang memiliki ilmu pengetahuan, keterampilan dan kualitas individu yang meliputi sikap, motivasi, nilai serta tingkah laku yang diperlukan untuk melaksanakan pekerjaan/ kegiatan. Jadi, kompetensi diartikan sebagai pengetahuan, keterampilan dan kemampuan individu yang langsung berpengaruh pada kinerja, Kinerja bagi wirausaha merupakan tujuan yang ingin dicapai. (Prabandari, 2013). Jadi bisa juga dikatakan motivasi mempengaruhi kinerja.

Menurut Nurmanaf (2006: 272), kontribusi pendapatan dari satu jenis kegiatan terhadap total pendapatan rumah tangga tergantung pada produktivitas faktor produksi yang digunakan dari jenis kegiatan yang bersangkutan. Stabilitas pendapatan rumah tangga cenderung dipengaruhi dominasi sumber-sumber pendapatan. Jenis-jenis pendapatan yang berasal dari luar sektor pertanian umumnya tidak terkait dengan musim dan dapat dilakukan setiap saat sepanjang tahun.(Handayani, 2009)

Penelitian yang dilakukan oleh Handayani (2009) menemukan bahwa seluruh responden ibu rumah tangga anggota KWT Boga Sari berada pada usia produktif kerja, sebagian besar responden mempunyai tingkat pendidikan yang cukup tinggi (setara SLTA). Rata-rata curahan jam kerja responden ibu rumah tangga anggota KWT Boga Sari pada kegiatan membuat jajan olahan sebesar 4,27 jam per hari atau 18,36 jam per minggu dengan rata- rata 4 hari kerja per minggu.

Rata-rata sumbangan pendapatan responden ibu rumah tangga anggota KWT Boga Sari terhadap pendapatan keluarga sebesar sebesar Rp 429.754,00 atau $12,82 \%$ dari total pendapatan keluarga, dengan Produktivitas kerja responden sebesar Rp.3.594,00 per jam. Motivasi responden ibu rumah tangga anggota KWT Boga Sari adalah untuk menambah pendapatan keluarga, untuk mengisi waktu luang dengan kegiatan positif dan untuk mencari pengalaman. Sebagaian besar responden ibu rumah tangga anggota KWT Boga Sari $(83,3 \%)$ tidak mengalami hambatan, sedangkan 
$16,7 \%$ mengalami hambatan dalam hal pesaing dan tidak dapat membagi waktu untuk keluarga.(Handayani, 2009)

Dari hasil penelitian yang telah dilakukan oleh Haryanto (2008) ditemukan bahwa:

1. Pendapatan yang diperoleh oleh pekerja wanita tersebut menurut mereka dirasakan sudah cukup. Kontribusi pendapatan pekerja wanita terhadap pendapatan suami cukup signifikan.

2. Pendapatan wanita pemecah batu juga merupakan pendapatan keluarga. Peng- gunaan pendapatan merupakan penggunaan atau belanja untuk kebutuhan keluarga. Penggunaan untuk kebutuhan keluarga tersebut, antara lain untuk mencukupi kebutuhan pokok sehari-hari, untuk kebutuhan sekolah dan juga un- tuk kebutuhan yang sifatnya sosial, seperti arisan, bowo (menyumbang orang yang punya hajatan).

3. Para wanita pemecah batu ini rata-rata bekerja sebagai pemecah batu sehari selama 5 sampai dengan 8 jam (73,33 persen). Namun demikian waktu yang dialokasikan tersebut relatif fleksibel.(Haryanto, 2008)

Prabandari juga menyatakan berdasarkan hasil penelitiannya mengenai pengaruh motivasi dan kompetensi terhadap pengusaha, dapat diambil kesimpulan bahwa: 1. Motivasi dan kompetensi berpengaruh signifikan secara simultan terhadap kesuksesan pengusaha wanita. 2. Motivasi memiliki pengaruh dominan terhadap kesuksesan pengusaha wanita.(Prabandari, 2013)

Selanjutnya hasil penelitian Samir menunjukkan bahwa indikator dalam variabel manajemen sumber daya manusia memiliki pengaruh positif dan signifikan terhadap kinerja UKM catering. Berdasarkan hasil pengolahan data kuesioner yang sudah dijelaskan maka dapat disimpulkan bahwa manajemen sumber daya manusia berpengaruh kuat terhadap kinerja UKM catering(Samir, 2011).
Penelitian oleh Waluya Jati FKIP Universitas Muhammadiyah Malang dengan judul Analisis Motivasi Wirausaha Perempuan (Wirausahawati) di Kota Malang. Hasil penelitian menunjukkan secara bersama-sama variable prestasi, affiliasi, otonomi dan dominasi menjadi faktor yang terbukti secara bersama-sama dalam satu model sebagai penjelas tingkat intensi kaum perempuan memilih karir sebagai wirausaha di Kota Malang. Uji secara individual menunjukkan bahwa variabel prestasi dan dominasi terbukti menjadi faktor pendorong intensi dan motivasi perempuan dalam memilih karir sebagai wirausaha. Sedangkan 2 faktor yang lain, yaitu affiliasi dan otonomi tidak berpengaruh signikan. Hal ini berarti motivasi kaum perempuan memang didorong oleh keinginan berpretasi sama dengan kaum laki-laki dan menunjukkan diri bisa mandiri sebagai wirausaha. Secara model, hasil pengujian menunjukkan bahwa ketiga variabel tersebut memang sangat fit untuk digunakan sebagai model dengan tingkat koefisien regresi meski hanya rendah yaitu sebesar $37,6 \%$.

\section{METODE}

Penelitian ini dilakukan di Komplek perumahan sederhana tepatnya Perumahan Wisma Kualu Permai RT 02/RW03 Tarai Bangun Kecamatan Tambang Kabupaten Kampar Provinsi Riau.

Populasi dalam penelitian ini adalah ibu-ibu rumah tangga yang berada di Komplek Perumahan Wisma Kualu Permai RT 01 RW 03 Panam yang memiliki Tabulampot berjumlah 18 orang. Sampel dari penelitian ini diambil dari semua populasi (diambil secara sensus atau dengan teknik sampling jenuh) yang sekaligus dijadikan sebagai responden penelitian.

Data primer yang digunakan dalam penelitian ini, yakni data yang secara langsung dari sumber data atau data yang diperoleh dari hasil survey di lapangan. Pengambilan data dengan menggunakan 
kuesioner yang sebelumnya disusun dari penggunaan teori pendapatan, motivasi dan kinerja. Disamping itu juga dengan wawancara.

Teknik analisis data yang digunakan dalam penelitian ini adalah dianalisa secara deskriptif kuantitatif, yaitu dengan melakukan penalaran logis. Data temuan lapangan disusun secara sistematis yang menunjukkan bagaimana peran aktif wanita selain sebagai ibu rumah tangga dalam peningkatan ekonomi keluarga.

\section{HASIL}

Setelah proklamasi RI berdasarkan surat keputusan Gubernur Militer Sumatera Tengah nomor : 10/GM/STE/49 tanggal 9 November 1949, Kabupaten Kampar merupakan salah satu Daerah Tingkat II di Provinsi Riau terdiri dari kawedanaan Pelalawan, Pasir Pangarayan, Bangkinang dan Pekanbaru Luar Kota dengan Ibu Kota Pekanbaru. Kemudian berdasarkan UndangUndang No. 12 Tahun 1956 ibu kota Kabupaten Kampar dipindahkan ke Bangkinang dan baru terlaksana tanggal 6 Juni 1967 dengan alasan Bangkinang terletak di tengah-tengah daerah Kabupaten Kampar, yang dapat dengan mudah untuk melaksanakan pembinaan di seluruh wilayah kecamatan dan sebaliknya.

Pada awalnya, Kabupaten Kampar terdiri dari 19 kecamatan dengan dua pembantu Bupati sesuai dengan Surat Keputusan Gubernur Kepala Daerah Tingkat I Riau Nomor : KPTS. 318VIII1987 tanggal 17 Juli 1987. Pembantu Bupati Wilayah I berkedudukan di Pasir Pangarayan dan Pembantu Bupati Wilayah II di Pangkalan Kerinci. Dengan diberlakukannya UndangUndang Nomor 53 tahun 1993 Junto surat Keputusan Menteri Dalam Negeri Nomor 75 tahun 1999 tanggal 24 Desember 1999, maka Kabupaten Kampar resmi dimekarkan menjadi 3 Kabupaten yaitu Kabupaten Pelalawan, Kabupaten Rokan Hulu dan Kabupaten Kampar. Kabupaten Kampar terdiri dari 20 Kecamatan dan 219 desa/kelurahan.

Kabupaten Kampar memiliki luas wilayah 1.092.819,71 ha, berada pada $100^{\circ} 28^{\circ} 30^{\circ}-101^{\prime} 14^{\circ} 30^{\circ}$ Bujur Timur (BT) dan $01^{\prime} 00^{\prime} 40^{\circ}$ Lintang Utara (LU) sampai $00^{\prime} 27^{\circ} 00^{\circ}$ Lintang Selatan. Kampar berbatasan dengan :

- Sebelah Utara dengan Kabupaten Siak dan Kota Pekanbaru

- Sebelah Timur dengan Kabupaten Siak dan Kabupaten Pelalawan

- Sebelah Selatan dengan Kabupaten Kuantan Singingi

- Sebelah Barat dengan Kabupaten Rokan Hulu dan Provinsi Sumatera Barat

Ibukota Kabupaten Kampar adalah Kota Bangkinang yang berjarak sekitar 85 KM dari Ibukota Provinsi Riau, Pekanbaru. Jumlah penduduk Kabupaten Kampar pada tahun 2011 adalah 713.078 jiwa. Sebagian besar, 67,22 \% penduduk Kampar bekerja di sektor pertanian, perkebunan dan kehutanan serta persentase terkecil, 0,22\% bekerja di sektor industri. Secara umum, potensi daerah berkaitan dengan sumber alam bersandar pada sektor perkebunan, pertanian, kehutanan, industri dan pertambangan.

Di daerah perbatasan antara Kampar dan kota Pekanbaru banyak dibangun komplek-komplek perumahan sederhana khususnya di daerah Panam dan sekitarnya sehingga Panam dikenal sebagai Sentra Komplek Perumahan Sederhana. Sudah menjadi rahasia umum bahwa masyarakat yang hidup di komplek perumahan sederhana mempunyai lahan yang terbatas dan bahkan boleh dikatakan minim. Maka dari itu, Tabulampot bisa menjadi salah satu solusinya.

Berdasarkan BPS, penggolongan umur produktif kerja yaitu dari 15-64 tahun. Dari hasil penelitian ini diketahui bahwa keseluruhan responden tergolong usia produktif. Dimana rata-rata umur responden adalah 40 tahun dengan kisaran umur 31 tahun smpai 50 tahun. 1 orang diantara responden merupakan seorang janda yang ditinggal mati suami sehingga ibu rumah tangga tersebut yang memegang peranan penting dalam kegiatan ekonomi keluarga. 
Selanjutnya dilihat dari pendidikan responden, diketahui rata-rata pendidikan responden adalah lulusan SLTA. Dimana sebanyak 13 orang lulusan SLTA $(72,2 \%)$, 1orang lulusan D1, 3 orang lulusan S1 dan hanya 1 orang lulusan SD. Hal ini menunjukkan juga bahwa responden mempunyai potensi untuk mengembangkan usaha karena tingkat pendidikan merupakan cerminan kualitas SDM. Sebagaimana menurut Nurhayati (2008), bahwa semakin tinggi tingkat pendidikan seseorang, maka akan cepat tanggap terhadap perkembangan teknologi dan kemampuan seseorang(Handayani, 2009)

Dari penelitian diketahui bahwa responden telah bermukim atau tinggal di komplek perumahan sederhana ini rata-rata 9,5 tahun. Jumlah tanggungan keluarga merupakan faktor yang menentukan jumlah pengeluaran setiap keluarga. Dari hasil penelitian juga diketahui rata-rata jumlah tanggungan keluarga adalah 3 orang dengan kisaran 1 sampai 4 orang. Dilihat dari suku, hasil penelitian menemukan bahwa mayoritas responden adalah bersuku Minang yaitu sejumlah 10 orang $(55,6)$, bersuku jawa 4 orang $(22,2 \%)$, bersuku Melayu 3 orang $(16,7 \%)$ dan Aceh hanya 1 orang (5,6\%).

\section{Pengelolaan Tabulampot Rumah Tangga Agar Dapat Menambah Pendapatan Keluarga}

Dari penelitian diketahui jenis tanaman yang ditanam oleh para ibu rumah tangga yang tinggal di perumahan sederhana ini adalah diantaranya: mangga, klengkeng, anggur, jambu air madu, belimbing madu, matoa, rambutan, lemon, jeruk kasturi dan jeruk madu.

\section{Motivasi Membuat Tabulampot}

Faktor penggerak yang sangat dasar bagi adanya aktifitas ekonomi adalah adanya kebutuhan manusia. Dalam hal ini masingmasing orang atau kelompok memiliki dominasi kebutuhan yang berbeda-beda (Gitosudarmo dan Mulyono, 2001:176).(Prabandari, 2013) Dari hasil penelitian juga diketahui bahwa pada umumnya motif para ibu rumah tangga melakukan kegiatan Tabulampot ini adalah rasa senang. Dimana yang menyatakan senang sebanyak 9 orang $(50 \%)$, menyatakan mengisi waktu luang sebanyak 3 orang $(16,7 \%)$ dan menyatakan memanfaatkan lahan kosong sebanyak 6 orang $(33,3 \%)$. Jadi bisa dikatakan bahwa motivasi ibu-ibu rumah tangga perumahan sederhana dalam membuat tabulampot pada umumnya adalah karena senang.

\section{Evaluasi Hasil Tabulampot}

Sebenarnya hasil dari Tabulampot bisa bernilai ekonomis tapi sangat disayangkan, hasil penelitian menemukan hanya 2 orang yang menyatakan pernah memberi nilai hasil tanaman tersebut dalam bentuk rupiah, selebihnya menyatakan tidak pernah. Hal ini berarti bahwa pada umumnya responden memiliki pengetahuan dan pemahaman yang minim tentang ilmu ekonomi. Walaupun mayoritas motif mereka membuat Tabulampot adalah karena senang tetapi tanpa mereka sadari, hal tersebut juga bernilai ekonomi yaitu bisa dijadikan sebagai ajang refresing untuk penghilang stres karena rutinitas yang dijalani setiap harinya.

\section{Pendapatan Keluarga}

Hasil penelitian menunjukkan ratarata pendapatan total keluarga antara $\mathrm{Rp} 3$ juta s/d Rp 6 juta. Hal ini dapat dilihat dari tabel 1 berikut:

Tabel 1. Pendapatan Keluarga Responden perbulan tahun 2017

\begin{tabular}{|l|l|c|c|}
\hline No & $\begin{array}{l}\text { Pendapatan } \\
\text { Keluarga } \\
\text { perbulan }\end{array}$ & $\begin{array}{l}\text { Jumlah } \\
\text { rumah } \\
\text { tangga }\end{array}$ & $\%$ \\
\hline 1 & $<$ Rp 3 juta & 7 & $\begin{array}{c}38,9 \\
\%\end{array}$ \\
\hline 2 & $\begin{array}{c}\text { Rp3 juta s/d Rp } \\
\text { 6 juta }\end{array}$ & 10 & $\begin{array}{c}55,6 \\
\%\end{array}$ \\
\hline 3 & < Rp 6 juta & 1 & $5,6 \%$ \\
\hline & Jumlah & 18 & $100 \%$ \\
\hline
\end{tabular}

Data olahan penelitian 2017

Dari tabel 1 di atas dapat dilihat bahwa sebagian besar keluarga responden 
(55,6\%) mempunyai pendapatan Rp3 juta s/d Rp 6 juta perbulannya. Hal ini menunjukkan bahwa keluarga responden telah mampu memenuhi kebutuhan hidup minimum di Kabupaten Kampar karena rata-rata kebutuhan hidup minimum keluarga di Kabupaten Kampar adalah Rp 2.315.002 perbulannya.

\section{Pengeluaran keluarga Responden}

Tabel.2. Pengeluaran keluarga Responden perbulan Tahun 2017

\begin{tabular}{|l|l|l|l|}
\hline No & $\begin{array}{l}\text { Pengeluaran } \\
\text { Keluarga } \\
\text { perbulan }\end{array}$ & $\begin{array}{l}\text { Jumlah } \\
\text { rumah } \\
\text { tangga }\end{array}$ & $\%$ \\
\hline 1 & $<2$ juta & 5 & $27,8 \%$ \\
\hline 2 & $\begin{array}{l}1 \text { juta s/d } \\
\text { juta }\end{array}$ & 11 & $61,1 \%$ \\
\hline 3 & $>4$ juta & 2 & $11,1 \%$ \\
\hline & Jumlah & 18 & $100 \%$ \\
\hline
\end{tabular}

Data Olahan Penelitian 2017

Dari tabel 2. di atas bisa dilihat bahwa kebanyakan rumah tangga responden memiliki pengeluaran sebesar 2 juta s/d 4 juta. Hal ini memperlihatkan bahwa pengeluaran keluarga responden tidak melebihi pendapatan. Ini artinya kebutuhan keluarga masih terpenuhi setiap bulannya dan bahkan bisa bersisa untuk ditabung.

\section{PEMBAHASAN}

\section{Dampak Usaha Tabulampot Terhadap Pendapatan Keluarga}

Dari hasil penelitian diketahui bahwa Usaha Tabulampot yang dilakukan oleh kaum ibu yang bermukim di Perumahan sederhana ini masih berdampak kecil bagi peningkatan pendapatan keluarga (16,7\%). Dimana dari hasil penelitian didapatkan hanya 3 orang yang menyatakan bahwa hasil tanaman tersebut dapat menambah pendapatan keluarga.

\section{Kendala-Kendala yang Dihadapi Dalam Melakukan Kegiatan Tabulampot}

Hasil penelitian menunjukkan kendala yang paling banyak dirasakan ibuibu dalam menjalankan kegiatan Tabulampot adalah susah mendapatkan tanah yang subur dan terkendala dalam hal pemeliharaan/ perawatan tabulampot itu sendiri. Banyak yang mengeluhkan tentang jambu madu mereka yang berulat. Kendala -kendala lain yang dirasakan responden dalam mekukan kegiatan Tabulampot ini diantaranya adalah hama/serangga, tidak berbuah dan sempitnya lahan.

\section{SIMPULAN}

Berdasarkan hasil penelitian maka dapat ditarik kesimpulan berkaitan dengan dampak Usaha Tabulampot terhadap pendapatan keluarga adalah sebagai berikut:

1. Dalam pengelolaan usaha Tabulampot dilihat dari perencanaan, diketahui dari hasil penelitian bahwa ibu rumah tangga belum melakukan perencanaan dengan baik. Hal ini terlihat dari motif mereka melakukan kegiatan Tabulampot kebanyakan hanya karena senang. Mereka juga kurang melakukan pengontrolan terhadap usaha yang telah dilakukan khususnya evaluasi hasil usaha.

2. Dampak Usaha Tabulampot terhadap pendapatan keluarga belumlah begitu terasa yaitu hanya $16,7 \%$.

3. Mayoritas kendala yang dirasakan para kaum ibu dalam melakukan kegiatan Tabulampot adalah dalam hal perawatannya.

Saran yang bisa diberikan dalam rangka meningkatkan kinerja Tabulampot ibu-ibu rumah tangga dalam menghadapi kondisi ekonomi adalah sebagai berikut:

a. Untuk bisa mengelola usaha Tabulampot dengan baik dan menguntungkan maka perlu adanya perencanaan yang matang sebelum menanam Tabulampot dan selalu melakukan perawatan serta pengontrolan dengan melakukan evaluasi terhadap hasil usaha sehingga dapat meningkatkan pendapatan rumah tangga..

b. Untuk meningkatkan dampak hasil 
tabulampot terhadap pendapatan keluarga, perlulah dilakukan evaluasi. Hobbi yang dilakukan dan dievaluasi dengan baik bisa meningkatkan pendapatan keluarga

c. Dari kendala yang dirasakan para ibu rumah tangga, akan bisa menjadi peluang bagi pedagang Tabulampot untuk menawarkan jasa konsultasi dan perawatan Tabulampot

\section{DAFTAR RUJUKAN}

Handayani, M. T. (2009). Kontribusi Pendapatan Ibu Rumah Tangga Pembuat Makanan Olahan Terhadap Pendapatan Keluarga. PIRAMIDA Jurnal Kependudukan Dan Pengembangan Sumber Daya Manusia, V(1), 1-9.

Haryanto, S. (2008). Peran Aktif Wanita Dalam Peningkatan Pendapatan Rumah Tangga Miskin: Studi Kasus Pada Wanita Pemecah Batu Di Pucanganak Kecamatan Tugu Trenggalek *. Jurnal Ekonomi Pembangunan, 9(2), 216-227.

Prabandari, S. P. dan N. H. R. (2013). Motivasi dan kompetensi pengaruhnya terhadapkesuksesan pengusaha wanita. Peran perbankan syariah dalam penguatan kapasitas umkm menuju kemandirian ekonomi nasional, 150-158.

Samir, A. (2011). Identifikasi Faktor-Faktor yang Mempengaruhi Kinerja UKM Catering di Kota Bandung. Jurnal Manajemen Teknologi, 10(2), 162184. Retrieved from http://www.sbm.itb.ac.id/wpcontent/uploads/2011/08/4-alfin.pdf

Sari, M. (2014). Enterpreneur terhadap kinerja ukm di kota medan maya. Jurnal riset akuntansi dan bisnis $\mathrm{Vol}$ 14 No . 1 / Maret 2014, 14(2002), $52-65$.
Wibowo, I. W., Ananda, G. R., Setiawan, R., Prahendra, Z. A., \& Adelin, D. (2015).

“TRANSFARMER”Nursery

Holtikultura dalam Bentuk

Tabulampot. 415073(Angkatan), 1-36.

Wicaksono, G. (2015). Meningkatkan Kinerja Umkm Industri Kreatif Melalui Pengembangan Kewirausahaan Dan Orientasi Pasar: Kajian Pada Peran Serta Wirausaha Wanita Di Kecamatan Moyudan, Kabupaten Sleman, Propinsi Diy. Jurnal Sosio Humaniora, 3(4), 27-39.

Wiguna, A. A., \& Ekadewi, L. (2016). Penerapan Sistem Tabulampot Pada Jenis Tanaman Mangga dan Jeruk di Kelurahan Karangrejo Kecamatan Sumbersari Kabupaten Jember. Seminar Hasil Penelitian Dan Pengabdian Masyarakat Dana BOPTN Tahun 2016, ISBN : 978-602-14917-3-7 Penerapan, 211-214. 